\title{
Az Alzheimer-kór heterogenitása
}

\author{
Balázs Nóra dr. - Kovács Tibor dr.
}

Semmelweis Egyetem, Általános Orvostudományi Kar, Neurológiai Klinika, Budapest

\begin{abstract}
A neurodegeneratív betegségek között az Alzheimer-kór a leggyakoribb kórforma. Morbiditása és mortalitása világszerte egyre gyorsabb ütemben növekszik, ezáltal szociális és gazdasági hatása is folyamatosan fokozódó terhet jelent a társadalomra. Az elmúlt néhány évtizedben jelentős előrelépés történt az Alzheimer-kór megismerésében, számos biomarker támogatja a diagnózis felállítását, tüneti terápiát szolgáló gyógyszerek kerültek bevezetésre. Az Alzheimerkór klinikai megjelenése, lefolyása, viselkedése rendkívül változatos képet mutat, felismerése a rendelkezésre álló eszközök ellenére is kihívást jelenthet a nagy tapasztalattal bíró klinikusok számára is. Munkánk céljául tûztük ki, hogy összefoglaljuk az Alzheimer-kór genetikai, patológiai és klinikai jellemzőit, segítve ezzel a betegség jobb megés felismerését. Bemutatjuk a jelenleg érvényben lévő patológiai és klinikai irányelvek kritériumrendszereit, az újabb klasszifikációs szemléleteket. Részletesen ismertetjük az Alzheimer-kór heterogenitását genotípus és fenotípus szintjén egyaránt. Elemezzük a típusos és atípusos megjelenési formák jellemzőit, a társuló kórállapotoknak a megjelenésre és a progresszióra gyakorolt hatását.
\end{abstract}

Orv Hetil. 2021; 162(25): 970-977.

Kulcsszavak: Alzheimer-kór, dementia, neurodegeneratív betegségek

\section{Heterogeneity of Alzheimer's disease}

\begin{abstract}
Alzheimer's disease is the most prevalent neurodegenerative disorder. Morbidity and mortality of Alzheimer's disease are increasing worldwide causing important social and economic burden on the society. Over the past few decades, significant progress has been made in the understanding of the pathogenesis of Alzheimer's disease, several biomarkers support the diagnosis and drugs for symptomatic therapy had been introduced. The clinical manifestations and the course of Alzheimer's disease have a variable picture, so - despite the diagnostic opportunities - its diagnosis could be a challenge for highly experienced clinicians as well. The aim of our work was to summarize the genetic, pathological and clinical characteristics of Alzheimer's disease, thus helping to better understand and recognize the disease. We present the criteria systems of the currently valid pathological and clinical guidelines with the most recent classification approaches. The heterogeneity of Alzheimer's disease at both genotype and phenotype levels is described in detail. The characteristics of typical and atypical manifestations and the effect of co-pathologies on the appearance and progression of Alzheimer's disease are also discussed.
\end{abstract}

Keywords: Alzheimer's disease, dementia, neurodegenerative, disease

Balázs N, Kovács T. [Heterogeneity of Alzheimer's disease]. Orv Hetil. 2021; 162(25): 970-977.

(Beérkezett: 2020. december 7.; elfogadva: 2020. december 29.)

\section{Rövidítések}

AChEi $=$ (acetylcholinesterase inhibitor) acetilkolin-észterázgátló; $\mathrm{APOE}=$ apolipoprotein $\mathrm{E} ; \mathrm{APP}=$ amiloidprekurzor protein; $\mathrm{A} / \mathrm{T} / \mathrm{N}=$ amiloid/tau/neuronpusztulás; $\mathrm{A} \beta$ = béta-amiloid; $\mathrm{CERAD}=($ Consortium to Establish a Registry for Alzheimer's Disease) konzorcium az Alzheimer-kór nyilvántartásának létrehozására; FDG = fluoro-dezoxi-glükóz; FUS = fused in sarcoma protein; MMSE $=($ Mini-Mental State Examination) Mini Mentál Teszt; MRI = (magnetic resonance imaging) mágnesesrezonancia-képalkotás; NIA-AA $=($ National Institute on Aging-Alzheimer's Association) Országos Örege- dési Intézet-Alzheimer Szövetség; NMDA = N-metil-d-aszparaginsav; $\mathrm{PET}=$ (positron emission tomography) pozitronemissziós tomográfia; PSEN = preszenilin; REM (rapid eye movement) gyors szemmozgás; TAR $=$ (trans-activation response) transzaktivációs válasz; TDP43 = TAR DNS-kötő protein -43

A dementia kognitív deficittel és lebenytünetekkel járó szindróma, mely a betegek mindennapi aktivitásában vagy munkájában zavart okoz. A dementia 90\%-a a 65 év 
feletti népességet érinti, ebben a populációban a leggyakoribb formák az Alzheimer-kór (az összes dementia akár 60-70\%-a), a vascularis dementia és a Lewy-testes dementia [1]. A dementia okozta egyre növekvő morbiditás és mortalitás - egyes országokban (Anglia és Skócia) a vezető halálokok közé tartoznak - hatalmas terhet jelentenek a társadalomra egészségügyi, szociális és gazdasági téren egyaránt [2, 3].

A dementiák közös jellemzője a szerzett, progresszív, irreverzibilis idegsejtpusztulás. Hátterükben nem vascularis eredet esetén kóros fehérjefelszaporodás igazolható a neuronokban és a gliasejtekben, illetve Alzheimer-kór és prionbetegségek esetén az extracellularis kompartmentekben. Az aggregátumok, illetve az azokat felépítő szolúbilis mono- és oligomerek kezdetben a szinapszisoknak, később a neuronoknak a pusztulásához vezetnek. Az alapvető jelentőségú fehérjék a béta-amiloid (A $\beta)$, a tau, az $\alpha$-szinuklein, a TAR DNS-kötő protein-43 (TDP43), a 'fused in sarcoma' (FUS) és a prionprotein [4]. A degeneratív kórképek a dominálóan jelen lévő proteinek alapján négy fó patológiai csoportba oszthatók (Alzheimer-kór, a frontotemporalis lebeny degenerációs

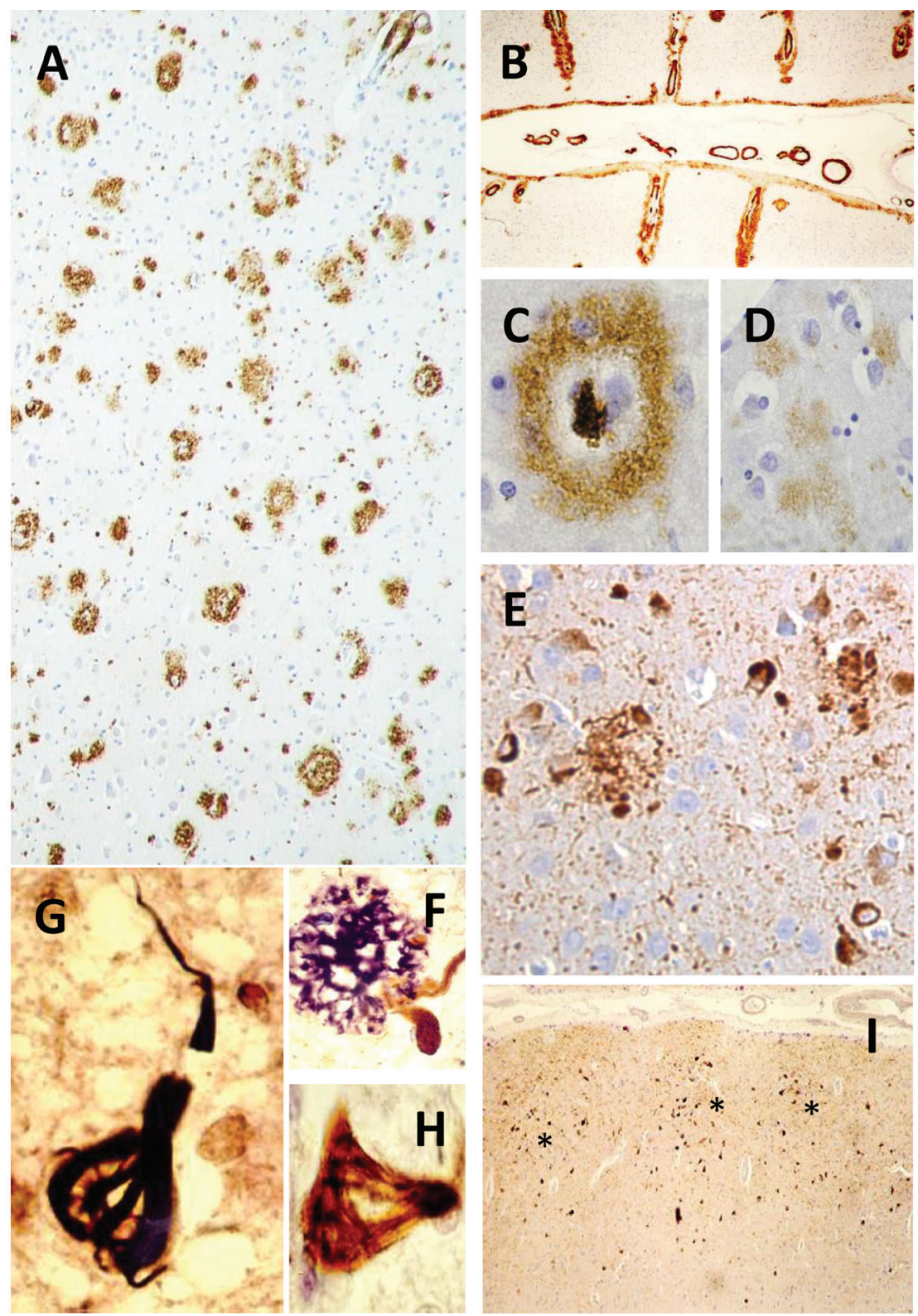

1. ábra $\mid$ Az Alzheimer-kór patológiája, saját felvétel. A: Kiterjedt $A \beta$-lerakódás a gyrus frontalis superiorban. $A \beta$-immunhisztokémia, 20×. B: A 3 -angiopathia az occipitalis kéregben. A $\beta$-immunhisztokémia, 4x. C: Klasszikus (ring-with-core) szenilis plakk. A $\beta$-immunhisztokémia, 100×. D: Diffúz A $\beta$ depozíció a parietalis kéregben. A $\beta$-immunhisztokémia, 60×. E: Neurofibrillaris kötegek és neuritplakkok a gyrus frontalis superiorban. Tau-AT8immunhisztokémia, 40×. F: Neuritplakk a gyrus frontalis superiorban Alzheimer-kórban. A $\beta$ (lila) és foszfo-tau (barna) kettős jelöléses immunhisztokémiai festés, 60×. G: Neurofibrillaris köteg mitralis sejtben a bulbus olfactoriusban. Gallyas-féle ezüstözés, 100×. H: Neurofibrillaris köteg mitralis sejtben a bulbus olfactoriusban. Tau-1-immunhisztokémia, 100×. I: Neurofibrillaris kötegek az entorhinalis kéreg II. rétegének sejtszigeteiben (*). TP001-tau-immunhisztokémia, $6 \times$

$\mathrm{A} \beta=$ béta-amiloid 
spektruma, Parkinson-szindrómák és prionbetegségek) [5]. Az egyes patológiai kategóriákba egymással átfedést mutató, változatos klinikai megjelenésű szindrómák sorolhatók. A továbbiakban részletesen az Alzheimer-kór klinikopatológiai jellegzetességeivel, változatosságával foglalkozunk, a 2020-ig terjedő időszak új tudományos eredményeinek összefoglalásával.

\section{Az Alzheimer-kór klinikopatológiai jellemzői}

Az Alzheimer-kór kialakulásához két fehérje együttes felhalmozódása vezet: az extracellularis $A \beta$ a szenilis plakkokat, az intracellularis tau a neurofibrillaris kötegeket alkotja (1. ábra).

A tau-zárványtestek kialakulása megelőzi az A $\beta$ plakkok létrejöttét [6], míg a depozitumok megjelenése akár évtizedekkel is megelőzheti a klinikai tünetek kialakulását [7]. A fehérjeaggregátumok terjedésének mintázatát az A $\beta$-plakkokra a Thal-féle [8], míg a tau esetében a Braak-féle stádiumok [9] írják le. A két zárványtest együttes jelenléte az Alzheimer-kór neuropatológiai diagnózisának feltétele, melyet 2012-ben a National Institute on Aging-Alzheimer's Association (NIA-AA) patológiai irányelve írt le [10] (1. táblázat) [11].

A patológiai diagnózis teljes bizonyossággal csak post mortem állapítható meg, de egyre több diagnosztikai eszköz jelenik meg, melyek in vivo alkalmazhatók a molekuláris és szerkezeti változások kimutatására (2. táblázat) [12-18].

A biomarkerek alapján az egyének az $\mathrm{A} / \mathrm{T} / \mathrm{N}(\mathrm{A}$, mint amiloid; $\mathrm{T}$, mint tau; és $\mathrm{N}$, mint neuronpusztulás) rendszer szerint is kategorizálhatók Alzheimer-kór-kockázati csoportokba. A klasszifikáció lényege, hogy a vizsgált alany a három kategória mentén pozitív vagy negatív besorolást kap, mely alapján megbecsülhető az Alzheimerkór-patológia jelenléte vagy hiánya. $\mathrm{A}-/ \mathrm{T}-/ \mathrm{N}-$, illetve minden egyéb A- kombinációjú besorolás esetén az Alzheimer-kór-patológia kizárható, az $\mathrm{A}+/ \mathrm{T}-$ kérdéses (Alzheimer-típusú patológiai elváltozás), míg az A+/T+ esetekben az Alzheimer-kór diagnózisa nagy valószínúséggel kimondható $[12,13]$. Az A/T/N-klasszifikáció tartalmazza a kognitív (C) paramétereket is, aszimptómás, enyhe kognitív deficit és dementia formájában, illetve lehetőséget teremt a magas kockázatú egyének követésére, valamint a jövőben talán az oki terápiára alkalmasak kiválasztására is.

A patológiai irányelvek mellett a NIA-AA 2011-ben a korábbi alapelvek aktualizálásával az Alzheimer-kór-stádiumok klinikai kritériumrendszereit is kidolgozta. Három szintet különböztet meg egymástól: a preklinikai stádiumot [19], az enyhe kognitív zavart [20] és az Alzheimer-kór-dementia állapotát [21] (2. ábra).

A preklinikai stádiumban a biomarkerek pozitivitása igazolható, de az érintettek tünetmentesek, azonosításuk nehéz [19]. A betegek felismerésében segítséget jelenthet az irányelvekben nem szereplő szubjektív kognitív hanyatlás fennállása. Szubjektív kognitív hanyatlás esetén a beteg a korábbi szellemi képességeinek csökkenéséről számol be, de ez neuropszichológiai tesztekkel még nem mérhető mértékű [22]. A szubjektív kognitív hanyatlást mutató betegek körében magasabb az Alzheimer-kór biomarkereinek jelenléte, és a későbbiekben gyakrabban alakul ki náluk a dementia mértékét elérő deficit [23].

Az enyhe kognitív zavar esetén a betegeknél - a nemet, az életkort és az iskolázottságot figyelembe véve -

1. táblázat |A NIA-AA-féle neuropatológiai ABC-klasszifikáció [10] alapján

\begin{tabular}{llccc}
\hline & & \multicolumn{3}{c}{ B: neurofibrillaris köteg } \\
\cline { 3 - 5 } & & \multicolumn{3}{c}{ Braak-stádiumok } \\
\hline A: A 3 -plakk & C: neuritplakk & B0-B1. & B2. & B3. \\
\hline Thal-féle stádiumok & CERAD & (nincs vagy I/II.) & (III/IV.) & N/VI.) \\
\hline A0. (0.) & C0. (nincs) & Nem AK & Nem AK & Nem AK \\
\hline Al. (1/2.) & C0. vagy C1. (nincs v. alig) & Alacsony & Alacsony & Alacsony \\
\cline { 2 - 5 } & C2. vagy C3. (mérsékelt v. gyakori) & Alacsony & Közepes & Közepes \\
\hline A2. (3.) & C0-C3. & Alacsony & Közepes & Közepes \\
\hline A3. $(4 / 5)$. & C0. vagy C1. (nincs v. alig) & Alacsony & Közepes & Közepes \\
\cline { 2 - 4 } & C2. vagy C3. (mérsékelt v. gyakori) & Alacsony & Közepes & Magas \\
\hline
\end{tabular}

A: Thal-féle stádiumok: $0 .=$ nincs $A \beta$-plakk; $1 .=$ csak a neocortex területén; 2. = az allocortex régiójában is; 3 . = a köztiagy, a striatum és a basalis elöagy kolinerg magjaiban; 4. = az agytörzsi magvak jelentős részében; 5. = a kisagyban is kimutathatók A $\beta$-plakkok [8].

B: Braak-stádiumok: I/II. - a transentorhinalis régióban, III/IV. - a limbicus régióban, V/VI. - az isocorticalis régióban is kimutathatók neurofibrillaris kötegek [9].

C: CERAD- (Consortium to Establish a Registry for Alzheimer's Disease) stádiumok: Bielschowsky-festés alapján szemikvantitatívan meghatározott neuritplakk-sûrüség a frontalis, temporalis és parietooccipitalis gyrusokból [11].

Az ABC-klasszifikáció a három kritériumrendszer egyesítésével határozza meg az Alzheimer-kór valószínúségét. A post mortem igazolt közepes és magas besorolás igazolja a beteg életében adott klinikai Alzheimer-kór diagnózisát.

$\mathrm{A} \beta$ = béta-amiloid; NIA-AA = Országos Öregedési Intézet-Alzheimer Szövetség 
2. táblázat |Az Alzheimer-kór diagnosztikus eszközei

\begin{tabular}{|c|c|c|c|}
\hline Módszerek & Mit vizsgál? & Szenz. & Spec. \\
\hline \multicolumn{4}{|c|}{ Biokémiai markerek (liquor)** } \\
\hline $\mathrm{A} \beta_{42}$ & $\mathrm{~A} \beta$-depozitumok jelenléte $(\mathrm{A})$ & $96,4 \%$ & $76,9 \%$ \\
\hline $\begin{array}{l}\text { Foszforilált tau } \\
\text { (P-tau) }\end{array}$ & $\begin{array}{l}\text { Neurofibrillaris kötegek } \\
\text { jelenléte }(\mathrm{T})\end{array}$ & $67,9 \%$ & $73,1 \%$ \\
\hline Totális tau (T-tau) & Neuronpusztulás (N) & $69,6 \%$ & $92,3 \%$ \\
\hline P-tau/A $\beta$ arány & \multirow{2}{*}{$\begin{array}{l}\text { Tünetmentesekben konverzió- } \\
\text { becslésre használható }\end{array}$} & $91,1 \%$ & $71,2 \%$ \\
\hline $\mathrm{T}$-tau/A $\beta$ arány & & $85,7 \%$ & $84,6 \%$ \\
\hline \multicolumn{4}{|c|}{ Strukturális képalkotás } \\
\hline Koponya-MRI* & $\begin{array}{l}\text { Agyi patoanatómia, } \\
\text { atrophiamintázat, } \\
\text { hippocampalis térfogat elemzése }\end{array}$ & $86,0 \%$ & $86,3 \%$ \\
\hline \multicolumn{4}{|c|}{ Funkcionális képalkotás } \\
\hline FDG-PET * & $\begin{array}{l}\text { A neuronpusztulás mértéke, } \\
\text { eloszlása }(\mathrm{N})\end{array}$ & $86,3 \%$ & $86,6 \%$ \\
\hline \multicolumn{4}{|c|}{ Fehérjeazonosító képalkotás } \\
\hline Amiloid-PET** & Az amiloidplakkok eloszlása (A) & $90,8 \%$ & $90,0 \%$ \\
\hline Tau-PET & $\begin{array}{l}\text { A neurofibrillaris kötegek } \\
\text { eloszlása }(\mathrm{T})\end{array}$ & $89,9 \%$ & $90,6 \%$ \\
\hline
\end{tabular}

*Magyarországon elérhető; * korlátozottan érhető el

A módszerek mögött zárójelben feltüntetett betűk az A/T/N klasszifikáció [12] szerinti csoportosítást jelzik, az A az amiloidplakkokat, a T a tau-depozitumokat, az $\mathrm{N}$ a neuronpusztulást jelöli. Az Nkategória nem patológiaspecifikus, bármilyen okból bekövetkezett neuronpusztulás esetén jelez. A markerek meghatározott sorrendben jelzik az abnormalitást: elsóként a liquor- $\mathrm{A} \beta_{42}$ és amiloid-PET, majd a liquor-tau-kimutatás és FDG-PET következik, ezt követi az MRI a klinikai tünetek jelentkezése előtt. A foszforilált és a totális tau liquorszintjei, a koponya-MRI-volumetria és az FDG-PET a Braak-féle stádiumokkal, vagyis a neurofibrillaris kötegek mennyiségével mutat korrelációt $[12,13]$. A liquorszenzitivitás- és -specificitás értékeit boncolás során igazolt Alzheimer-kóros betegek mintái alapján vizsgálták [14]. A liquormarkerek külön kevésbé alkalmasak előre jelezni a tünetessé váló betegeket, arányuk vizsgálata megbízhatóbb erre a célra [15]. Az MRI- és FDG-PET-értékek az Alzheimer-kór-dementiával diagnosztizáltakra vonatkoznak [16]. Az amiloid-PET-adatok patológiai diagnózisra vonatkoznak, klinikai korreláció nélkül [17]. A tauPET-adatok Alztheimer-kór vs. nem Alzheimer-kóros neurodegeneratív betegek vizsgálatából származnak [18].

$\mathrm{A} \beta$ = béta-amiloid; FDG = fluoro-dezoxi-glükóz; $\mathrm{MRI}=$ mágnesesrezonancia-képalkotás; PET = pozitronemissziós tomográfia; Spec. = specificitás; Szenz. = szenzitivitás

neuropszichológiai tesztekkel igazolható kognitív deficit mérhető [20], mely azonban a mindennapi aktivitást nem károsítja. Az érintettek követése során nem feltétlenül következik be progresszió, a betegek stagnálhatnak, vagy akár javulhatnak. Egészséges idős populációhoz viszonyítva az enyhe kognitív zavar esetén Alzheimer-kórdementia kialakulására 9,5-szer nagyobb az esély, az éves konverziós arány 6,5\% körüli [24]. Emiatt a betegek szoros követése szükséges, hogy időben észleljük a progressziót, és mihamarabb elkezdhessük a rendelkezésre álló terápiát. A konverzió a neuropszichológiai tesztek és biomarkerek kombinált alkalmazása esetén 70\% körüli pontossággal is becsülhető, önálló modalitásként a noninvazív, a többi eszközhöz képest könnyebben hozzáférhető neuropszichológiai tesztek szenzitivitása a legmagasabb $[25,26]$. Az Alzheimer-kór-dementia kritériumai (2. ábra) között felsorolt kognitív tünetek enyhe kognitív zavar esetén is fennállhatnak, így amnesticus, illetve nem amnesticus, valamint egy vagy több domént érintő enyhe kognitív zavar differenciálható. A neuropszichológiai felmérések alapján nagyobb az esély konverzióra, ha a betegnél amnesticus típusú enyhe kognitív zavar vagy több domént érintő deficit azonosítható [27].

Az Alzheimer-kór-dementia kritériumait a 2. ábra szemlélteti. A diagnózist követően a betegek túlélése átlagosan 3,5-8 év [28]. A betegség enyhe, közepes és súlyos stádiumát különböztethetjük meg, a neuropszichológiai teszteket (például Mini Mentál Teszt [MMSE]), a mindennapi aktivitásra gyakorolt hatást és a globális klinikai állapotot figyelembe véve. Az enyhe (MMSE: 2620 pont) és középsúlyos (MMSE: 19-10 pont) esetekben az acetilkolin-észteráz-gátló ( $\mathrm{AChEi-)} \mathrm{készítmények}$ mielőbbi megkezdése javasolt a kognitív funkciók, a napi aktivitás, a viselkedéssel kapcsolatos tünetek javítására [29]. A középsúlyos stádiumtól az AChEi-készítmények mellé a memantin - a rendelkezésre álló egyetlen N-metil-d-aszparaginsav (NMDA)-receptor-gátló - bevezetése is ajánlott [30]. Az előforduló klinikai formákat és lefolyást a következő fejezetben részletezzük.

\section{Az Alzheimer-kór heterogenitása}

Az Alzheimer-kórt genetikai, patológiai és klinikai sokszínúség jellemzi. A típusos patológiához társulhat más fehérjék (a leginkább az $\alpha$-szinuklein és a TDP43) felhalmozódása, illetve vascularis károsodások, melyek a lefolyást nagyban befolyásolják. Az egyes klinikai megjelenésekhez MRI-vel, illetve PET-tel kimutatható, eltérő eloszlású atrophiamintázat, valamint metabolizmuscsökkenés társulhat. Az Alzheimer-kór-dementia kritériumaiban meghatározott domének érintettsége alapján is eltérő altípusokat különböztethetünk meg. Mindezeket figyelembe véve fenotípus- és genotípus-felosztás mentén kívánjuk ismertetni a főbb formákat.

\section{Fenotipus}

\section{Tünettani felosztás}

Amnesticus (tipusos) forma

Az Alzheimer-kór leggyakoribb megjelenési formája. Időskorban, 60-70 év felett jelentkeznek az első tünetek: kezdetben amnesticus funkciózavar észlelhető, majd a betegség előrehaladtával nyelvi és végrehajtási domének érintettsége is társul [1]. Az amnesticus funkciózavar részeként az epizodikus memória kifejezett károsodása típusos Alzheimer-kór esetén [31]. A tau-fehérje-depozitumok megjelenése a hippocampusok, a medialis temporalis lebeny érintettségével indul, és az aggregátumok 


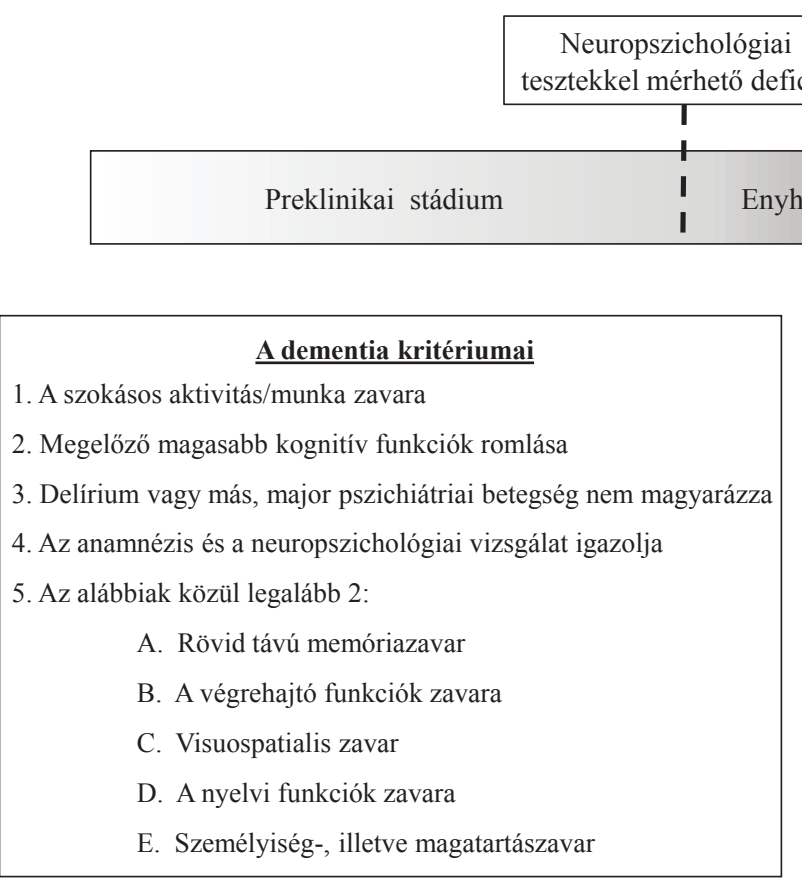

\begin{tabular}{|} 
Az Alzheimer-kór-dementia kritériumai \\
1. Lappangó kezdet \\
2. A kognitív funkciók dokumentált romlása \\
3. A kezdeti/legnyilvánvalóbb kognitív zavar alapján \\
A: Amnesticus típus \\
B: Nem amnesticus típus \\
- Nyelvi \\
- Visuospatialis \\
- Végrehajtási funkciók zavara \\
4. Más klinikai szindróma hiánya (például vascularis, Lewy-testes, \\
frontotemporalis dementia)
\end{tabular}

2. ábra

Az Alzheimer-kór klinikai stádiumai és az Alzheimer-kór-dementia kritériumai. A NIA-AA az Alzheimer-kór klinikai kritériumait lehetséges (possible) és valószínű (probable) szinten határozza meg, az ábrán a 'valószínű' kategóriát tüntettük fel. A tünetekre alapuló beosztást a biomarkerek jelenléte támaszthatja alá, biztos diagnózis csak szövettani elemzéssel nyerhető

NIA-AA = Országos Öregedési Intézet-Alzheimer Szövetség

lerakódása fokozatosan terjed a temporoparietalis kéreg felé [9]; jellemző a kétoldali, szimmetrikus sorvadás és a csökkent metabolizmus [32].

\section{Temporalis variáns Alzheimer-kór}

A típusos Alzheimer-kórnál későbbi életkorban kezdődő, lassú progressziójú forma. A típusos Alzheimer-kór kockázatát fokozó apolipoprotein $\mathrm{E}(A P O E)$-є4-allél (bővebben ld. a sporadikus genetikai előfordulásnál) előfordulása ezekben a betegekben alacsonyabb [32]. Tiszta epizodikus és szemantikus memóriazavar jellemzi a visuospatialis és a praefrontalis funkciók relatív megkíméltsége mellett [33]. A kóros fehérjefelhalmozódás, atrophia, metabolizmuscsökkenés elsősorban izoláltan a medialis temporalis lebenyt érinti, a típusos formához képest a temporoparietalis kéreg érintettsége hiányzik [34].

A temporalis variáns Alzheimer-kór elkülönítésében nehézséget okoz az elsődleges, életkorral összefüggő taupathia (primary age-related tauopathy) is. Elsődleges, életkorral összefüggő taupathia esetén az Alzheimerkórral megegyező morfológiájú neurofibrillaris kötegek (Braak-stádium $\leq 4)$ mellett $A \beta$-plakkok nem vagy csak diffúz gócokban igazolhatók (Thal 0-2, CERAD 0), így a NIA-AA patológiai kritériumrendszer (1. táblázat) szerint alacsony valószínűségü Alzheimer-kór-kategóriába is sorolható lehet. Az elsődleges, életkorral összefüggő taupathiára szintén jellemző az $A P O E-\varepsilon 4$-allél alacsony gyakorisága, a lassú progresszió és a domináns epizodikus memóriazavar mellett nem kifejezett visuospatialis tünetek [35].

\section{Frontalis variáns Alzheimer-kór}

A legritkább típus. Fiatalabb életkorban jelentkeznek az első tünetek, és gyakrabban fordul elő férfiak körében. Elsősorban a végrehajtási funkciókat és/vagy a viselkedést érinti. Klinikailag a viselkedési variáns frontotemporalis dementiát utánozhatja [1]. Elkülönítésükben segíthet, hogy Alzheimer-kór esetén a viselkedési funkciók kevésbé, míg a kognitív domének jobban és hamarabb érintettek a frontotemporalis dementiához viszonyítva. A frontalis variáns Alzheimer-kór fennállásakor az atrophia mintázata jobban hasonlít a típusos Alzheimerkórra, mint a frontotemporalis dementiára (az utóbbira a frontalis és temporalis lebenyek elülső részének [sokszor aszimmetrikus] sorvadása jellemző) [36].

\section{Visuospatialis variáns Alzheimer-kór}

A döntően a jobb occipitoparietalis vagy occipitotemporalis lebenyt érintő degeneráció következtében alakul ki [32]. Főként a visualis funkciók érintettek, a memória-, a végrehajtó, a nyelvi és a viselkedésdomének a kezdeti stádiumban többnyire megkíméltek. Főbb kezdeti tünete lehet a visualis agnosia, a prosopagnosia, a Bálint- vagy Gerstmann-szindróma, az öltözködési, vagy ideomotoros apraxia [1]. Ez a forma a posterior corticalis atrophia alap klinikai feltételeit teljesíti, a posterior corticalis atrophia azonban nemcsak Alzheimer-kór, de egyéb patológia (Lewy-testes dementia vagy corticobasalis degeneráció/szindróma, prionbetegség) talaján is kialakulhat [37]. 


\section{Nyelvi variáns Alzheimer-kór}

A nyelvi érintettség esetén két különböző formát különíthetünk el: a progresszív non-fluens és a logopéniás progresszív aphasiát. A típusos formához képest mindkettő fiatalabb életkorban jelentkezik, gyorsabb lefolyás jellemző rájuk [32], illetve a visuospatialis variánshoz hasonlóan más patológia is állhat a hátterükben (például a frontotemporalis lebeny degenerációja tau- vagy TDP43zárványtestekkel) [38]. A progresszív non-fluens aphasia bal hátsó frontoinsularis dominanciájú károsodás révén alakul ki. Jellemző a kifejezett agrammatizmus és a fonemikus paraphasiák jelenléte [38]. Logopéniás progreszszív aphasia a Sylvius-árok körüli és parietalis lebeny atrophia esetén valószínú. Fluens, de lassú, grammatikailag helyes beszéd jellemzi, az ismétlés károsodott [38]. A progresszív non-fluens aphasia és a logopéniás progreszszív aphasia nem keverendő össze a típusos Alzheimerkór késői stádiumában észlelhető aphasiával, mely fluens jellegű beszédzavar anomiával, szemantikus paraphasiákkal, és fokozatosan felületes diszlexiává és zsargonbeszéddé súlyosbodik [32].

\section{Társuló patológia}

Az életkor előrehaladtával a vascularis rizikófaktorok és a fehérjeaggregátumok előfordulása egyre növekvő tendenciát mutat [39]. Ezzel összhangban az Alzheimerkór klinikai diagnózisú betegek nagyjából 40-50\%-ánál igazolható tiszta Alzheimer-kór-patológia, többségüknél vascularis laesiók, illetve egyéb proteinopathiák jelenléte is kimutatható [40]. A patológiai kritériumrendszer szerint közepes vagy magas besorolású Alzheimer-kór esetén a társuló kórfolyamat jelenléte a négyszeresére növeli a dementia kialakulásának kockázatát [39]. Minden társuló patológiának additív vagy szinergista hatása van az Alzheimer-kórra, de kölcsönhatásuk módja még nem tisztázott [40]. A leggyakoribb, párhuzamosan igazolt kórképek a vascularis dementia, a Lewy-testes dementia és a TDP43-protein felszaporodásával járó betegségek.

A kevert patológiájú Alzheimer-kóros esetek akár háromnegyedénél igazolhatók az agyi keringészavar nyomai, és kb. negyedüknél igazolható a vascularis dementia jelenléte is $[40,41]$. A lokalizáció, a méret és a károsodások száma befolyásolja a tünetek súlyosságát, bár az infarktusok száma jelentősebb hatással bír a kognitív deficitre, mint egy nagyobb méretú laesio önmagában [41].

Az $\alpha$-szinukleinből álló Lewy-testek felhalmozódása közelítőleg 60\%-ban figyelhető meg; az esetek kevesebb mint 20\%-ában alakul ki Lewy-testes dementia és Alzheimer-kór együttesen $[40,41]$. A Lewy-testes dementiát parkinsonizmus, fluktuáló kognitív deficit, visualis hallucinációk, REM- (rapid eye movement) alvászavarok jelenléte mellett az antipszichotikumokra való fokozott érzékenység jellemzi [42]. A Lewy-testes dementia és az Alzheimer-kór párhuzamos jelenléte módosítja a kognitív deficit jellegét, de nem változtatja meg annak mértékét [40]. A fiatalabb korban kezdődő tünetek és a visualis hallucinációk jelenléte vetheti fel a kevert patológia jelenlétét, de az Alzheimer-kór és a Lewy-testes dementia együttes diagnosztizálása biomarkerek használatával is kihívást jelent [42].

Alzheimer-kórban a TDP43-fehérje lerakódása az esetek 20-50\%-ában igazolható, fóleg az amygdala és a medialis temporalis lebeny területén [40]. A TDP43-protein jelenléte kevésbé befolyásolja a tünetkezdet idejét, viszont a tízszeresére növeli a dementia kialakulásának esélyét, és rontja annak lefolyását [41]. Minél nagyobb mértékben van jelen a TDP43-fehérje, annál kifejezettebb hippocampusatrophiát és epizodikus memóriazavart okoz [41].

\section{Dignitás}

A 60-70 éves életkorban diagnosztizált Alzheimer-kórt követően a medián túlélés 7-10, míg 90 év felett kevesebb mint 3 év [28], de ettől jelentős eltérés is előfordulhat. A tünettani felosztás ismertetésekor látható volt, hogy a különböző dominanciájú érintettség eltérő lefolyással társul: a temporalis variánsban szenvedőknél akár évekig stabilak maradhatnak a kognitív tünetek, és kifejezetten lassú előrehaladás jellemző, szemben a frontalis variáns rosszabb prognózisával. A tau-aggregátumok megoszlása alapján a típusos formákon belül (a Braakstádiumoknak megfelelve) is megkülönböztethető a hippocampust kevésbé (míg a neocorticalisokat viszonylag súlyosabban érintő), illetve a limbicus régiókat intenzívebben (a neocorticalisokat kevésbé) érintő altípusok [40]. Az előbbi fiatalabb életkorban jelentkező, súlyosabb, gyorsabb lefolyású, kiterjedtebb kognitív doménkárosodással járó betegséget idéz elő, míg az utóbbi későbbi életkorban kezdődik, és lassabb progresszióval bír [43]. Ismertek különleges, a prionbetegségek dinamikáját mutató formák is, ezekben az esetekben megtévesztő lehet a kognitív tünetek gyors progressziója és a kiterjedt fokális kórjelek, gyakran myoclonusok társulása [44].

\section{Genotipus}

\section{Familiáris}

A familiáris formára a korai tünetkezdet $(<65$, általában 30-50 év) és a gyorsabb progresszió jellemző; az összes Alzheimer-kóros eset kevesebb mint 5\%-át teszi ki [1]. Hátterében az amiloidprekurzor protein $(A P P)$, a preszenilingének (PSEN1, PSEN2) kb. 230 különböző patogénmutációját azonosították, melyek az APP megváltozott szintézise, proteolízise révén túlzott $\mathrm{A} \beta$ felhalmozódáshoz vezetnek [45]. A PSEN1-mutáció az esetek 75-80\%-ában, az APP az esetek 15-20\%-ában, míg a PSEN2 kevesebb mint az esetek 5\%-ában mutatható ki, penetranciájuk közel 100\% [45]. Az APP a 21. kromoszómán található, így a Down-szindróma, amely ennek a kromoszómának a triszómiájaként is kialakulhat, a leggyakoribb ismert rizikófaktora a korai kezdetü $\mathrm{Alz-}$ heimer-kórnak [46].

A familiáris formák esetén gyakoribb az atípusos, fokális károsodáshoz köthető megjelenés, illetve gyakrabban 
társulnak az amiloid-angiopathia talaján kialakuló mikrovagy lebenyvérzések, illetve kisérbetegség [32]. A különböző génmutációkhoz a dementia mellé változatos neurológiai tünetek társulhatnak, mint myoclonusok, spasticus paraparesis, parkinsonizmus, epilepsziás rohamok, pszichózis, cerebelláris jelek [45, 47].

\section{Sporadikus}

Jellemzően 65 év felett alakul ki. Különböző mértékben hajlamosító genetikai tényezők ismertek (melyek a koleszterinmetabolizmust, az immunrendszert és az endocytosis mechanizmusait érintik, illetve emellett jelentős számban nem ismert funkcióval társulnak); ezeket a környezeti hatások, például az iskolázottság, a szociális vagy gazdasági helyzet, a fizikai aktivitás, a cardiovascularis status is befolyásolja $[48,49]$.

A sporadikus forma legerősebb genetikai faktora az $A P O E-\varepsilon 4$-allél, melyet a populáció $15-20 \%$-a hordoz hetero- vagy homozigóta formában [48]. Homozigóta hordozóknál az Alzheimer-kór gyakorisága 91\% is lehet, és az Alzhimer-kór tünetei akár 15 évvel korábban kezdődhetnek a nem hordozókhoz viszonyítva [50]. Az $A P O E$ által kódolt ApoE-fehérje többek közt a központi idegrendszer koleszterin-anyagcseréjében, illetve az $A \beta$ eltávolításban játszik szerepet [46]. Az $\varepsilon 4$-allél jelenléte esetén termelődő ApoE4-izoforma kevésbé effektíven tudja ellátni feladatát, szemben az $\varepsilon 2$-, illetve $\varepsilon 3$-allél jelenlétekor szintetizálódó ApoE2 és E3 formákkal, ami egyéb hatások közremúködésével kóros A $\beta$-felhalmozódáshoz vezethet [48]. Az $\varepsilon 4$-allél jelenléte az atherosclerosis, a 2-es típusú cukorbetegség kialakulásában, ezáltal a cardiovascularis károsodások fokozódásában is szerepet játszik, ami közvetve hozzájárulhat az Alzheimer-kór-patológia fokozott terjedéséhez [50].

\section{Következtetés}

A tünetek alapján a típusos (amnesticus) forma mellett előfordul az Alzheimer-kór temporalis, frontalis, visuospatialis és nyelvi variánsa is; a tünetek különbözőségén túl ezen altípusok kórlefolyása is eltérő. A dementia kialakulásának kockázatát jelentősen növelik a társuló patológiai kórfolyamatok, közülük a leggyakoribb a vascularis károsodás, a Lewy-testes patológia és a TDP43protein felszaporodása.

Az Alzheimer-kórról alkotott ismereteink köre fokozatosan bővül, a biomarkerek egyre pontosabb és gyorsabb felismerést tesznek lehetővé az atípusos esetekben is. Magyarországon ezek hozzáférhetősége jelenleg még korlátozott, így a diagnózist fơként fizikális vizsgálat, neuropszichológiai tesztek, képalkotó vizsgálatok, hosszú távú követés alapján állítjuk fel. Fontos az érintetteket minél előbb kiszürni, hogy a rendelkezésre álló terápiát a lehető leghamarabb megkezdhessük, javítva ezzel a betegek és gondozóik életminőségét.

Az Alzheimer-kór altípusainak azonosítására alkalmas biomarkerek vizsgálatának szerepe lesz a heterogén Alz- heimer-kór személyre szabott terápiájára irányuló gyógyszerfejlesztésekben is, mivel a heterogenitás szerepe jelentős lehet az elmúlt, közel két évtizedben tapasztalt gyógyszerfejlesztési próbálkozások kudarcában, különösen a betegség lefolyásának módosítását (disease modification) célzó antiamiloid monoklonális antitesteket használó vizsgálatokban.

Anyagi támogatás: A munkát a NAP2.0 (Nemzeti Agykutatási Program 2017-1.2.1-NKP-2017-00002) támogatta (K. T.).

Szerzői munkamegosztás: A szerzők a cikket közösen (B. N. 90\%, K. T. 10\%) írták. A cikk végleges változatát mindkét szerző elolvasta és jóváhagyta.

Érdekeltségek: A szerzőknek nincsenek érdekeltségeik.

\section{Irodalom}

[1] Elahi FM, Miller BL. A clinicopathological approach to the diagnosis of dementia. Nat Rev Neurol. 2017; 13: 457-476.

[2] Niu H, Alvarez-Alvarez I, Guillen-Grima F, et al. Trends of mortality from Alzheimer's disease in the European Union, 19942013. Eur J Neurol. 2017; 24: 858-866. [Erratum: Eur J Neurol. 2017; 24: 1200-1201.]

[3] Office for National Statistics. Deaths registered in England and Wales: 2019. Available from: https://www.ons.gov.uk/peoplepopulationandcommunity/birthsdeathsandmarriages/deaths/ bulletins/deathsregistrationsummarytables/2019 [accessed: October 25, 2020].

[4] Kovacs GG, Botond G, Budka H. Protein coding of neurodegenerative dementias: the neuropathological basis of biomarker diagnostics. Acta Neuropathol. 2010; 119: 389-408.

[5] Allegri RF. Moving from neurodegenerative dementias, to cognitive proteinopathies, replacing "where" by "what"... Dement Neuropsychol. 2020; 14: 237-242.

[6] Braak H, Del Tredici K. The pathological process underlying Alzheimer's disease in individuals under thirty. Acta Neuropathol. 2011; 121: 171-181.

[7] Morris JC. Early-stage and preclinical Alzheimer disease. Alzheimer Dis Assoc Disord. 2005; 19: 163-165.

[8] Thal DR, Rüb U, Orantes $M$, et al. Phases of $A \beta$-deposition in the human brain and its relevance for the development of $\mathrm{AD}$. Neurology 2002; 58: 1791-1800.

[9] Braak H, Braak E. Neuropathological stageing of Alzheimer-related changes. Acta Neuropathol. 1991; 82: 239-259.

[10] Hyman BT, Phelps CH, Beach TG, et al. National Institute on Aging-Alzheimer's Association guidelines for the neuropathologic assessment of Alzheimer's disease. Alzheimers Dement. 2012;8: $1-13$.

[11] Mirra SS, Heyman A, McKeel D, et al. The Consortium to Establish a Registry for Alzheimer's Disease (CERAD). Part II. Standardization of the neuropathologic assessment of Alzheimer's disease. Neurology 1991; 41: 479-486.

[12] Jack CR Jr, Bennett DA, Blennow K, et al. A/T/N: an unbiased descriptive classification scheme for Alzheimer disease biomarkers. Neurology 2016; 87: 539-547.

[13] Jack CR Jr, Bennett DA, Blennow K, et al. NIA-AA Research Framework: toward a biological definition of Alzheimer's disease. Alzheimers Dement. 2018; 14: 535-562.

[14] Shaw LM, Vanderstichele H, Knapik-Czajka M, et al. Cerebrospinal fluid biomarker signature in Alzheimer's disease neuroimaging initiative subjects. Ann Neurol. 2009; 65: 403-413. 
[15] Fagan AM, Roe CM, Xiong C, et al. Cerebrospinal fluid tau/ $\beta$ amyloid 42 ratio as a prediction of cognitive decline in nondemented older adults. Arch Neurol. 2007; 64: 343-349.

[16] Zhang D, Wang Y, Zhou L, et al. Multimodal classification of Alzheimer's disease and mild cognitive impairment. Neuroimage $2011 ; 55$ : 856-867.

[17] Salloway S, Gamez JE, Singh U, et al. Performance of $\left[{ }^{18} \mathrm{~F}\right]$ flutemetamol amyloid imaging against the neuritic plaque component of CERAD and the current (2012) NIA-AA recommendations for the neuropathologic diagnosis of Alzheimer's disease. Alzheimers Dement (Amst). 2017; 9: 25-34.

[18] Ossenkoppele R, Rabinovici GD, Smith R, et al. Discriminative accuracy of $\left[{ }^{18} \mathrm{~F}\right]$ flortaucipir positron emission tomography for Alzheimer disease vs other neurodegenerative disorders. JAMA 2018; 320: 1151-1162.

[19] Sperling RA, Aisen PS, Beckett LA, et al. Toward defining the preclinical stages of Alzheimer's disease: recommendations from the National Institute on Aging-Alzheimer's Association workgroups on diagnostic guidelines for Alzheimer's disease. Alzheimers Dement. 2011; 7: 280-292.

[20] Albert MS, DeKosky ST, Dickson D, et al. The diagnosis of mild cognitive impairment due to Alzheimer's disease: recommendations from the National Institute on Aging-Alzheimer's Association workgroups on diagnostic guidelines for Alzheimer's disease. Alzheimers Dement. 2011; 7: 270-279.

[21] McKhann GM, Knopman DS, Chertkow H, et al. The diagnosis of dementia due to Alzheimer's disease: recommendations from the National Institute on Aging-Alzheimer's Association workgroups on diagnostic guidelines for Alzheimer's disease. Alzheimers Dement. 2011; 7: 263-269.

[22] Jessen F, Amariglio RE, van Boxtel M, et al. A conceptual framework for research on subjective cognitive decline in preclinical Alzheimer's disease. Alzheimers Dement. 2014; 10: 844-852.

[23] Studart A Neto, Nitrini R. Subjective cognitive decline: the first clinical manifestation of Alzheimer's disease? Dement Neuropsychol. 2016; 10: 170-177.

[24] Mitchell AJ, Shiri-Feshki M. Rate of progression of mild cognitive impairment to dementia - meta-analysis of 41 robust inception cohort studies. Acta Psychiatr Scand. 2009; 119: 252-265.

[25] Cui Y, Liu B, Luo S, et al. Identification of conversion from mild cognitive impairment to Alzheimer's disease using multivariate predictors. PLoS ONE 2011; 6: e21896.

[26] Ewers M, Walsh C, Trojanowski JQ, et al. Prediction of conversion from mild cognitive impairment to Alzheimer's disease dementia based upon biomarkers and neuropsychological test performance. Neurobiol Aging 2012; 33: 1203-1214.

[27] Michaud TL, Su D, Siahpush M, et al. The risk of incident mild cognitive impairment and progression to dementia considering mild cognitive impairment subtypes. Dement Geriatr Cogn Dis Extra 2017; 7: 15-29.

[28] Brookmeyer R, Corrada MM, Curriero FC, et al. Survival following a diagnosis of Alzheimer disease. Arch Neurol. 2002; 59: 1764-1767.

[29] Birks JS, Harvey RJ. Donepezil for dementia due to Alzheimer's disease. Cochrane Database Syst Rev. 2018; 6: CD001190.

[30] Schmidt R, Hofer E, Bouwman FH, et al. EFNS-ENS/EAN guideline on concomitant use of cholinesterase inhibitors and memantine in moderate to severe Alzheimer's disease. Eur J Neurol. 2015; 22: 889-898.

[31] Tounsi H, Deweer B, Ergis AM, et al. Sensitivity to semantic cuing: an index of episodic memory dysfunction in early Alzheimer disease. Alzheimer Dis Assoc Disord. 1999; 13: 38-46.

[32] Lam B, Masellis M, Freedman M, et al. Clinical, imaging, and pathological heterogeneity of the Alzheimer's disease syndrome. Alzheimers Res Ther. 2013; 5: 1.
[33] Marra C, Villa G, Quaranta D, et al. Probable Alzheimer's dis ease patients presenting as "focal temporal lobe dysfunction" show a slow rate of cognitive decline. J Int Neuropsychol Soc. 2012; 18: 144-150.

[34] Cappa A, Calcagni ML, Villa G, et al. Brain perfusion abnormalities in Alzheimer's disease: comparison between patients with focal temporal lobe dysfunction and patients with diffuse cognitive impairment. J Neurol Neurosurg Psychiatry 2001; 70: 22-27.

[35] Bell WR, An Y, Kageyama Y, et al. Neuropathologic, genetic, and longitudinal cognitive profiles in primary age-related tauopathy (PART) and Alzheimer's disease. Alzheimers Dement. 2019; 15: 8-16.

[36] Ossenkoppele R, Pijnenburg YA, Perry DC, et al. The behavioural/dysexecutive variant of Alzheimer's disease: clinical, neuroimaging and pathological features. Brain 2015; 138: 27322749.

[37] Crutch SJ, Schott JM, Rabinovici GD, et al. Consensus classification of posterior cortical atrophy. Alzheimers Dement. 2017; 13: 870-884.

[38] Gorno-Tempini ML, Hillis AE, Weintraub S, et al. Classification of primary progressive aphasia and its variants. Neurology 2011; 76: 1006-1014.

[39] Kawas CH, Kim RC, Sonnen JA, et al. Multiple pathologies are common and related to dementia in the oldest-old: The $90+$ Study. Neurology 2015; 85: 535-542.

[40] Rabinovici GD, Carrillo MC, Forman M, et al. Multiple comorbid neuropathologies in the setting of Alzheimer's disease neuropathology and implications for drug development. Alzheimers Dement (N Y). 2017; 3: 83-91.

[41] Kapasi A, DeCarli C, Schneider JA. Impact of multiple pathologies on the threshold for clinically overt dementia. Acta Neuropathol. 2017; 134: 171-186.

[42] Outeiro TF, Koss DJ, Erskine D, et al. Dementia with Lewy bodies: an update and outlook. Mol Neurodegener. 2019; 14: 5.

[43] Murray ME, Graff-Radford NR, Ross OA, et al. Neuropathologically defined subtypes of Alzheimer's disease with distinct clinical characteristics: a retrospective study. Lancet Neurol. 2011; 10: 785-796.

[44] Schmidt C, Redyk K, Meissner B, et al. Clinical features of rapidly progressive Alzheimer's disease. Dement Geriatr Cogn Disord. $2010 ; 29: 371-378$.

[45] Wu L, Rosa-Neto P, Hsiung GY, et al. Early-onset familial Alzheimer's disease (EOFAD). Can J Neurol Sci. 2012; 39: 436445.

[46] Bagyinszky E, Youn YC, An SS, et al. The genetics of Alzheimer's disease. Clin Interv Aging 2014; 9: 535-551.

[47] Tang M, Ryman DC, McDade E, et al. Neurological manifestations of autosomal dominant familial Alzheimer's disease: a comparison of the published literature with the Dominantly Inherited Alzheimer Network observational study (DIAN-OBS). Lancet Neurol. 2016; 15: 1317-1325.

[48] Medina M, Khachaturian ZS, Rossor M, et al. Toward common mechanisms for risk factors in Alzheimer's syndrome. Alzheimers Dement (N Y). 2017; 3: 571-578.

[49] Hardy J, Bogdanovic N, Winblad B, et al. Pathways to Alzheimer's disease. J Intern Med. 2014; 275: 296-303.

[50] Liu CC, Liu CC, Kanekiyo T, et al. Apolipoprotein E and Alzheimer disease: risk, mechanisms and therapy. Nat Rev Neurol. 2013; 9: 106-118.

(Kovács Tibor dr.,

Budapest, Balassa u. 6., 1083

e-mail: kovacs.tibor@med.semmelweis-univ.hu)

A cikk a Creative Commons Attribution 4.0 International License (https://creativecommons.org/licenses/by/4.0/) feltételei szerint publikált Open Access közlemény, melynek szellemében a cikk bármilyen médiumban szabadon felhasználható, megosztható és újraközölhetö, feltéve, hogy az eredeti szerző és a közlés helye, illetve a CC License linkje és az esetlegesen végrehajtott módosítások feltüntetésre kerülnek. (SID_1) 